UDC 332; DOI 10.18551/rjoas.2022-01.07

\title{
MAPPING POTENTIAL STRATEGY OF VILLAGE OWNED ENTERPRISES (BUMDES) IN BATU CITY IN THE ERA OF DISRUPTION
}

\author{
Febriananda Faizal*, Wisynu Ari Gutama, Destyana Ellinggga P. \\ Department of Agricultural Socio-Economics, Faculty of Agriculture, University of Brawijaya, \\ Malang, Indonesia \\ *E-mail: $\underline{f \text { faizal@ub.ac.id }}$
}

\begin{abstract}
The era of disruption brought massive changes that fundamentally changed all existing systems, arrangements, and landscapes to new ways, one of which was digitalization. This poses many challenges as well as opportunities for BUMDes. BUMDes need to develop in accordance with the objectives of establishment and management according to the Government of Indonesia in the Regulation of the Minister of Villages Number 4 of 2015 article 3. One of the business models that can be applied simply is VRIO and SWOT analysis. The objectives of this study include (1) analyzing business potentials that can be used as advantages of BUMDes in Batu City, and (2) making alternative strategies that can be used as priorities for BUMDes business development in Batu City. The strategy that can be applied also by the strawberry barn is to hold joint discussions to provide ideas that can develop the strawberry barn business. Another strategy is to do promotions to introduce beautiful natural scenery to the strawberry barn through social media and add photo spots.
\end{abstract}

\section{KEY WORDS}

Agribusiness, village owned enterprises, potential development, VRIO, SWOT analysis.

The development of Village Owned Enterprises (BUMDes) is important for every village, considering that these efforts will affect the village economy and the welfare of the village community. The development of BUMDes will also affect the national economy. Ridlwan (2014) explains that the economic activities of BUMDes are part of an effort to improve the village and regional economy within the scope of the national economy. This is in accordance with Fitriska's (2017) statement, where national economic progress will be achieved if there is a good economy in the province, while economic progress at the provincial level will be achieved if economic activities at the district level are good and the economic progress of a district can be achieved because of the contribution of the activities. good rural economy. In addition, the development of BUMDes is also important which is in accordance with Indonesia's SDGs (Sustainable Development Goals), which has an important role to support the industrial, innovation, and infrastructure sectors. In accordance with Chikamawati's statement (2019) that BUMDes is the right of the village in accordance with the village law to take advantage of the village government to innovate in village development which can reduce the dependence of rural areas on the city, strengthen the role of the village as a production center, and the need for development resources.

The importance of the role of BUMDes is still not followed by good handling by the management of BUMDes themselves and the local government. Based on data from the Community and Village Empowerment Service (DPMD) recorded that the number of registered BUMDes in East Java is 6,080 , but only a few are classified as advanced business units, namely 456 while the rest are in the developing and beginner categories (Fajar, 2020). Several problems were identified such as product management, capital, unskilled human resources, marketing, product standard compliance, financial management, and investment. BUMDes needs development to serve the economic needs and public services of the village community, explore and utilize the economic potential of the village. The development of BUMDes can be done by adding types of businesses outside of the business that has been done and collaborating with several village economic institutions in 
terms of training and guidance which has the aim of improving community skills (Agunggunanto et al., 2016).

Good development in a BUMDes will affect the village, so that it can be used as an example by other BUMDes in business development and competition between the same businesses will be even greater. The business development strategy carried out needs to be studied further so that it can develop according to the changing times. The era of disruption brought massive changes that fundamentally changed all existing systems, arrangements, and landscapes to new ways, one of which was digitalization. This poses many challenges as well as opportunities for BUMDes, so it is necessary to study the readiness strategy of BUMDes.

One way that BUMDes can use to survive in the business competition carried out in the era of disruption is by implementing a business model to facilitate its business processes. Identification is carried out in this study which tends to see the potential and advantages of BUMDes in Batu City using the VRIO (Value, Rarity, Imitability, and Organization) method. Kim et al., (2015) state that specifically the impact of project management assets is on value, rarity, imitability, and organization in abbreviated as VRIO, a characteristic of the project management process that investigated by adopting a resource-based view of business enterprise capabilities. In the SWOT analysis to analyze the strengths and weaknesses (internal factors) as well as opportunities and threats (external factors) owned by BUMDes in Batu City in the strawberry barn business unit. According to Prasetyo et al., (2018) states that the scope will only focus on the business concept canvas model through nine key elements which will be followed by conducting a SWOT analysis to see strengths and weaknesses as well as existing opportunities and threats so as to be able to produce recommendations in the form of improvement strategies. current business model.

This research was conducted by looking at the importance of developing BUMDes to improve the welfare of rural communities and improve the village economy with the existence of village original income. As was done in BUMDes in Batu City. However, the number of competitors who have the same business because Batu City is a tourist city requires BUMDes in Batu City to continue to develop to be able to survive and develop from competitors by implementing good business models, knowing the potential that can be used as a BUMDes product advantage in Batu City which can be.

\section{METHODS OF RESEARCH}

Research on the development strategy and readiness of Village Owned Enterprises (BUMDes) in Batu City in the face of the post-pandemic disruption era. This research was conducted in BUMDes Raharjo Pandanrejo Village, Batu City. The time of the research will start from January to March 2021. The research was carried out with a quantitative descriptive approach. The data analysis technique used in this research is using VRIO analysis (value, rare, Imitability, organization), and SWOT analysis (strength, weakness, opportunity, threat). Both analyzes are in accordance with the stated objectives of this study. The stages of this research include: 1). Analyzing the business potential that is used as the advantage of BUMDes with the VRIO method, the business potential can be seen based on the condition of the internal environment consisting of resources and capabilities. 2). Making alternative strategies for developing BUMDes businesses in Batu City with a SWOT analysis approach, in making alternative strategies can be seen through considerations of the internal and external environment of BUMDes. If the identification stage of strengths, weaknesses, opportunities, and threats has been completed, then proceed with the calculation of the IFAS and EFAS matrices. Through the calculation of IFAS (Internal Factor Analysis Summary), namely the factors of strengths and weaknesses, while the calculation of EFAS (External Factor Analysis Summary) are the factors of opportunities and threats, and 3) Strengthening the competitiveness of BUMDes in Batu City in facing the era of disruption.

Determination of respondents in this study using purposive sampling technique. In this study using respondents from key informants. The key informants selected in this study were 2 people, namely the coordinator of the "Lumbung Strawberry" business unit and one 
treasurer of BUMDes Raharjo. The study was conducted using primary data. The primary data used in the study will be collected through interviews using questionnaires. The data from the results of this questionnaire relates to the business potential of BUMDes Raharjo which is also related to alternatives and priority development strategies applied to the business of BUMDes Raharjo.

1. VRIO Analysis (Value, Rare, Imitability, Organization). The purpose of the VRIO analysis in this study is to analyze the business potential that is used as an advantage of BUMDes Raharjo. The business potential can be seen based on the condition of the internal environment which consists of resources and capabilities.

Table 1 - Framework VRIO

\begin{tabular}{lllll}
\hline \multicolumn{4}{l}{ Are the resources and capabilities... } & \\
\hline Value & Rare & Imitability & Organization & Competitive Implications \\
\hline No & No & No & No & Competitive Disadvantage \\
Yes & No & No & & Competitive Equality \\
Yes & Yes & No & Yes & Temporary competitive advantage \\
Yes & Yes & Yes & Sustainable competitive advantage \\
\hline
\end{tabular}

Source: Wandrial (2011).

Explanation of the assessment criteria in the VRIO analysis that will be used in this study:

- Value, relates to whether or not the resources and capabilities of BUMDes Raharjo in responding to threats or opportunities seen in the business of BUMDes Raharjo;

- Rare, relates to the number of resources and capabilities of BUMDes Raharjo owned by competitors or at least the number of competitors who have similarities in resources and capabilities with BUMDes Raharjo;

- Imitability, describes how difficult or difficult the resources and capabilities of BUMDes Raharjo to be imitated by competitors;

- Organization, showing whether or not the resources and capabilities are managed and utilized to support the running of the BUMDes Raharjo business.

2. SWOT Analysis (Strong, Weakness, Opportunity, Threat). The use of SWOT analysis in this study aims to answer the purpose of this study, namely to create alternative strategies for business development of BUMDes Raharjo. In making alternative strategies, it can be seen through considerations of the internal and external environment of BUMDes Raharjo. If the identification stage of strengths, weaknesses, opportunities, and threats has been completed, then proceed with the calculation of the IFAS and EFAS matrices. Through the calculation of IFAS (Internal Factor Analysis Summary), namely the factors of strengths and weaknesses, while the calculation of EFAS (External Factor Analysis Summary) are factors of opportunities and threats.

Table 2 - IFAS Matrix

\begin{tabular}{llll}
\hline S): Strength & & & \\
\hline Internal Factor & Weight $(\mathrm{a})$ & Rating $(\mathrm{b})$ & Score $(\mathrm{a} \times \mathrm{b})$ \\
\hline Strength 1 & $\mathrm{a} 1$ & $\mathrm{~b} 1$ & $\mathrm{a} 1 \times \mathrm{b} 1$ \\
\hline Strength 2 & $\mathrm{a} 2$ & $\mathrm{~b} 2$ & $\mathrm{a} 2 \times \mathrm{b} 2$ \\
\hline Strength $\mathrm{n}$ & $\mathrm{An}$ & $\mathrm{bn}$ & $\mathrm{an} \times \mathrm{bn}$ \\
\hline$=$ Total Weight S & & & \\
\hline$(\mathrm{W}):$ Weakness & & Total Score S & \\
\hline Internal Factor & Weight $(\mathrm{a})$ & Rating $(\mathrm{b})$ & Score $(\mathrm{a} \times \mathrm{b})$ \\
\hline Weakness 1 & $\mathrm{a} 1$ & $\mathrm{~b} 1$ & $\mathrm{a} 1 \times \mathrm{b} 1$ \\
\hline Weakness 2 & $\mathrm{a} 2$ & $\mathrm{~b} 2$ & $\mathrm{a} 2 \times \mathrm{b} 2$ \\
\hline Weakness n & $\mathrm{An}$ & $\mathrm{Bn}$ & $\mathrm{an} \times \mathrm{bn}$ \\
\hline$=$ Total Weight W & & $=$ Total Score W & \\
\hline Total Internal Factor & 1,00 & $=$ Scor S + scor W & \\
\hline
\end{tabular}

Source: Ermaya and Nana (2019). 
Table 3 - EFAS Matrix

\begin{tabular}{|c|c|c|c|}
\hline \multicolumn{4}{|l|}{ (O): Opportunity } \\
\hline External Factor & Weight (a) & Rating (b) & Score $(a \times b)$ \\
\hline Opportunity 1 & a1 & b1 & $a 1 \times b 1$ \\
\hline Opportunity 2 & a2 & b2 & $\mathrm{a} 2 \times \mathrm{b} 2$ \\
\hline Opportunity $n$ & An & $\mathrm{Bn}$ & $a n \times b n$ \\
\hline$=$ Total weight $\mathrm{O}$ & & \multicolumn{2}{|c|}{$=$ Total Score O } \\
\hline \multicolumn{4}{|l|}{ (T): Threat } \\
\hline External Factor & Weight (a) & Rating (b) & Score $(a \times b)$ \\
\hline Threat 1 & a1 & b1 & $\mathrm{a} 1 \times \mathrm{b} 1$ \\
\hline Threat 2 & $\mathrm{a} 2$ & b2 & $a 2 \times b 2$ \\
\hline Threat $\mathrm{n}$ & An & bn & $a n \times b n$ \\
\hline$=$ Total Weight T & & \multirow{2}{*}{\multicolumn{2}{|c|}{$\begin{array}{l}=\text { Total Score T } \\
=\text { Score } \mathrm{O}+\text { Score } \mathrm{T}\end{array}$}} \\
\hline Total External Factor & 1,00 & & \\
\hline
\end{tabular}

Source: Ermaya and Nana (2019).

The most needed data in filling out the IFAS and EFAS matrix calculation tables are the data from the results of the identification of the strengths and weaknesses of the Raharjo BUMDes business which have been analyzed through VRIO analysis, and the results of descriptive analysis of the opportunities and threats of the Raharjo BUMDes. If the internal factors and external factors have been compiled, then the next step is to calculate the weight, rating, and score to determine the value of the $X$ and $Y$ coordinate axes in the SWOT analysis quadrant. The following is an explanation of each calculation stage:

a. Determination of weight. The weights are determined by making comparisons between each factor. The comparison uses a method of giving weights of 1 (less important), 2 (equally important), and 3 (very important). After being given a weight for each factor, then proceed with the calculation of the weight for each factor. The following formula is used to calculate the weight in each factor:

$$
a i=\frac{x i}{\sum x i}
$$

Where: $a i$ - i-th weight; $x i$ - i-th weight value; $\sum x i$ - sum of weight values; $i-1,2,3, \ldots n$.

After calculating the weight value for each factor, it is continued with the average calculation which will be entered into the IFAS and EFAS tables. The sum of the average weights on both internal and external factors is 1.00 .

b. Rating. Determination of the rating is done by giving an assessment of each internal factor and external factor. Assessment is done by giving a value of 1 (very weak), 2 (weak), 3 (strong), and 4 (very strong). After obtaining the value of each factor, then the average calculation is carried out where the results of the average will be entered into the IFAS and EFAS calculation tables.

c. Scoring. Determination of the score is done by multiplying the average value of the weight and rating in each factor. After knowing the scores on internal factors (strengths and weaknesses) and external factors (opportunities and threats), each score was added to the IFAS and EFAS tables.

The next stage is an analysis of the SWOT matrix to find alternative development strategies that can be applied to the BUMDes Raharjo business. The following is a SWOT matrix used to determine alternative strategies for developing BUMDes Raharjo.

Table 4 - SWOT Analysis Matrix

\begin{tabular}{|l|l|l|}
\hline External Internal & Strength (S) & Weakness (W) \\
\hline Opportunity $(\mathrm{O})$ & $\begin{array}{l}\text { SO Strategy } \\
\begin{array}{l}\text { Create strategies that use strengths to take } \\
\text { advantage of opportunities. Used when in } \\
\text { quadrant I }\end{array}\end{array}$ & $\begin{array}{l}\text { WO Strategy } \\
\text { Create strategies that minimize weaknesses to take } \\
\text { advantage of opportunities. Used when in quadrant III }\end{array}$ \\
\hline Threat $(\mathrm{T})$ & $\begin{array}{l}\text { Strategi ST } \\
\text { Create strategies that use strengths to address } \\
\text { threats. Used when in quadrant II }\end{array}$ & $\begin{array}{l}\text { Strategi WT } \\
\text { Create strategies that minimize weaknesses and avoid } \\
\text { threats. Used when in quadrant IV }\end{array}$ \\
\hline
\end{tabular}

Source: Dosinaen and Widya, (2019). 
If you have determined the alternative strategies obtained in the SWOT analysis matrix above, then the next step is to determine the values of the $X$ and $Y$ axes to be able to find out which strategy is the priority. The following is a SWOT analysis quadrant for the development of BUMDes Raharjo:

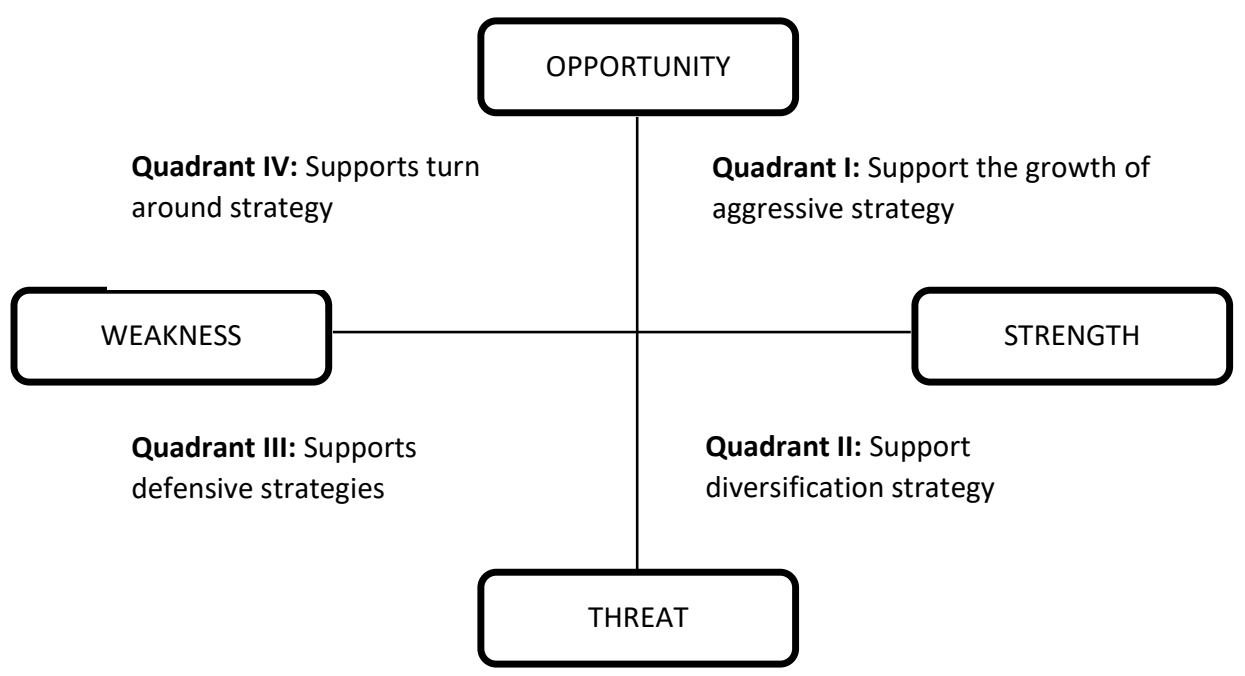

Figure 3 - SWOT Analysis Quadrant (Rangkuti, 2014)

\section{RESULTS AND DISCUSSION}

BUMDes Raharjo is located in Pandanrejo Village, Bumiaji District, Batu City, East Java. Pandanrejo village is located at an altitude of 700-800 meters above sea level, has an optimum air temperature of around $15-25^{\circ} \mathrm{C}$ and a minimum temperature of $3-5^{\circ} \mathrm{C}$, has an air humidity of $85-91 \%$ with a sun exposure period of $7.9-9.5$ hours/day, and has rainfall between $500-900 \mathrm{~mm} /$ year. Pandanrejo village consists of four hamlets namely Pandan Hamlet, Ngujung Hamlet, Kajar Hamlet, and Dadapan Hamlet. More precisely, BUMDes Raharjo is located in Pandan Hamlet. The potential that exists in Pandanrejo Village is supported by the natural potential of producing strawberries where the majority of the people in Pandan Hamlet are strawberry farmers which can be used by the village community to make strawberry-based food or drinks.

Strawberry barn is one of the business units of BUMDes Raharjo, Pandanrejo Village. This business unit of BUMDes Raharjo has become one of the characteristics of the Pandanrejo tourist village destination. The Strawberry Barn is operating in January 2019. The Strawberry Barn is located on Jln. Nurul Kamil, Pandan Hamlet, Pandanrejo Village, Batu City. The existence of the Strawberry Barn because it wants to help the welfare of strawberry farmers. Pandanrejo Village majority of the people are farmers, especially in Pandan Hamlet where the people there are strawberry farmers. Strawberry barns help strawberry farmers to sell their crops.

1. Mapping the Potential Advantages of the Strawberry Barn Business BUMDes Raharjo Batu City with VRIO. The business carried out by the strawberry barn which has the resources and capabilities can be used as a competitive advantage. The researcher gave a questionnaire to the strawberry barn manager using a google form. The results of the VRIO analysis of the resources from the strawberry barn can be seen in the table below.

There are seven resources owned by the strawberry barn. The seven resources are classified as "Competitive Equality". In other words, the resources owned have the same advantages as competitors. There is also one resource that is classified as "Sustainable competitive advantage", namely in having packaging for strawberries which is different from the others and rare. Strawberry barn uses duplex packaging which is coated with vinyl. The packaging used by the Strawberry Barn is quite expensive, if the competitor wants to imitate the same form of packaging, the competitor will need an expensive fee to realize it. In 
addition, there are resources that are classified as "temporary competitive advantage" where these resources create advantages so that they are not less competitive with other strawberry picking tours. However, the advantages of these resources can not last long which is temporary. This is because other strawberry picking tours can expand their strawberry gardens and add strawberry plants.

Table 5 - VRIO Analysis of Strawberry Barn Resources

\begin{tabular}{lllllll}
\hline Number & Resource & V & $\mathrm{R}$ & $\mathrm{I}$ & $\mathrm{O}$ & Competitive Implications \\
\hline 1 & Good reputation from consumers & $\sqrt{ }$ & $\mathrm{X}$ & $\mathrm{X}$ & $\mathrm{X}$ & Competitive Equality \\
2 & Family work culture & $\sqrt{ }$ & $\mathrm{X}$ & $\mathrm{X}$ & $\sqrt{ }$ & Competitive Equality \\
3 & Workers who help run the business & $\sqrt{ }$ & $\mathrm{X}$ & $\mathrm{X}$ & $\sqrt{ }$ & Competitive Equality \\
4 & Have an official account on social media & $\sqrt{ }$ & $\mathrm{X}$ & $\mathrm{X}$ & $\mathrm{X}$ & Competitive Equality \\
5 & Strategic place and adequate facilities & $\sqrt{ }$ & $\mathrm{X}$ & $\mathrm{X}$ & $\mathrm{X}$ & Competitive Equality \\
6 & Have regular customers & $\sqrt{ }$ & $\mathrm{X}$ & $\mathrm{X}$ & $\sqrt{ }$ & Competitive Equality \\
7 & Good quality strawberries (scent and taste) & $\sqrt{ }$ & $\mathrm{X}$ & $\mathrm{X}$ & $\sqrt{ }$ & Competitive Equality \\
8 & Different packaging from the others & $\sqrt{ }$ & $\sqrt{ }$ & $\sqrt{ }$ & $\sqrt{ }$ & Sustainable competitive advantage \\
9 & More visitor capacity than other tours & $\sqrt{ }$ & $\sqrt{ }$ & $X$ & $\sqrt{ }$ & Temporary competitive advantage \\
\hline
\end{tabular}

Source: Primary Data Processed (2021).

Furthermore, the results of the VRIO analysis of the capabilities of the strawberry barn can be seen in the table below.

Table 6 - VRIO Analysis of Strawberry Barn Capabilities

\begin{tabular}{lllllll}
\hline Number & Capability & V & $R$ & I & O & Competitive Implications \\
\hline 1 & Solid teamwork & $\sqrt{ }$ & $X$ & $X$ & $\sqrt{ }$ & Competitive Equality \\
2 & Ability to establish good communication with consumers & $\sqrt{ }$ & $X$ & $X$ & $\sqrt{ }$ & Competitive Equality \\
3 & Ability to establish good communication with work partners & $\sqrt{ }$ & $X$ & $X$ & $\sqrt{ }$ & Competitive Equality \\
4 & Knowledge in financial management & $\sqrt{ }$ & $X$ & $X$ & $\sqrt{ }$ & Competitive Equality \\
5 & Utilizing social media in the marketing process & $\sqrt{ }$ & $X$ & $X$ & $\sqrt{ }$ & Competitive Equality \\
6 & Strawberry fruit sorting ability & $\sqrt{ }$ & $X$ & $X$ & $\sqrt{ }$ & Competitive Equality \\
7 & Ability to control the quality of strawberries & $\sqrt{ }$ & $X$ & $X$ & $\sqrt{ }$ & Competitive Equality \\
8 & Innovate to create product excellence & $\sqrt{ }$ & $\sqrt{ }$ & $\sqrt{ }$ & Sustainable competitive advantage \\
9 & Meet the supply of strawberries & $\sqrt{ }$ & $X$ & $X$ & $X$ & Competitive Equality \\
10 & Taking care of strawberry picking tourism facilities & $\sqrt{ }$ & $X$ & $X$ & $X$ & Competitive Equality \\
11 & Assistance of visitors during strawberry picking tour & $\sqrt{ }$ & $X$ & $X$ & $\sqrt{ }$ & Competitive Equality \\
\hline
\end{tabular}

Source: Data Primer Diolah (2021).

It can be seen that the capabilities possessed by the Strawberry Barn are 10 capabilities which are classified as "Competitive Equality". The capabilities possessed by the Strawberry Barn as a whole are also shared by other competitors where most competitors are also doing the same thing. There is also one capability that is classified as "Sustainable competitive advantage", which is to innovate to create product advantages. Based on the results of interviews with the strawberry barn manager, the strawberry barn has made innovations to create competitive advantages, such as managing strawberry processed products and improving packaging for fresh strawberries using duplex paper coated with vinyl. This can be used as an advantage because the materials for the packaging have not been widely used by competitors so that the packaging of the Strawberry Barn is different from competitors. The Strawberry Barn has planned to make one of the innovations that can be used as an advantage over the Strawberry Barn, which is to make dried strawberry products. The product is inspired by dried strawberry products that are in South Korea and are still rare in Indonesia. The shape of the product is like a whole strawberry except that the fruit is machine-dried. If competitors want to imitate these innovations, it will cost a lot of money to realize them.

2. Mapping of Priority Strategies for Business Development of Strawberry Barns BUMDes Raharjo in Batu City with SWOT Analysis. SWOT analysis uses a comparison between internal factors, namely strengths and weaknesses and external factors, namely opportunities and threats. This analysis was carried out to determine the factors inside and outside one of the business units of BUMDes Raharjo, namely Strawberry Barn, Pandanrejo Village that affected the development of the Strawberry Barn. 
Internal factors can be identified as strengths and weaknesses for the development of strawberry barns.

- Strengths:

1) Good reputation from consumers. The Strawberry Barn gets a pretty good rating on reviews on Google by consumers, with a rating of 4.4 .

2) Family work culture and solid teamwork. The Strawberry Barn has a slightly different teamwork than most ventures. This strawberry barn has a family work culture.

3) Workers who help run the business. There are five workers in the strawberry barn. Each worker has a different job desk, such as the fresh strawberry section, strawberry picking tour guide, financial management, and website.

4) Have an official account on social media and use it for marketing. Strawberry barn has official accounts on several social media, such as Instagram, Facebook, and websites. The purpose of the official account is to reach wider consumers, provide information related to the strawberry barn, and carry out promotions.

5) Strategic location and has good facilities. Strawberry barn has a strategic location, in the middle of Batu City. The road access to the strawberry barn is also easy to find and the road conditions are quite good but the road access is a bit narrow. The facilities owned, such as toilets, cafes, parking lots, mosques, pavilions to rest, and interesting and good photo spots.

6) Ability to establish good communication with consumers and partners. The strawberry barn always strives to establish good relationships with consumers so that consumers are willing to repurchase fresh strawberries and return to strawberry picking tours. The Strawberry Barn always communicates with work partners, of course, to maintain the relationship between the two, so that they can help each other in their respective businesses.

7) Financial management ability. The method of financial management carried out by the Strawberry Barn has been applied quite well by taking detailed and routine notes.

8) Have regular customers. In general, strawberry picking tourist visitors and fresh strawberry consumers will return to the strawberry barn every year, every month and even every week.

9) More visitor capacity than competitors. The land of the strawberry barn is less than 2.3 hectares where there are strawberry gardens and buildings, such as parking lots, pavilions, and others. The land belongs to BUMDes Raharjo.

10) Ability to maintain facilities. Every strawberry barn worker cleans the barn every day. In addition to labor, farmers who rent land in the strawberry barn also maintain strawberry gardens.

11) Good service to visitors. The regulation of the strawberry barn for workers is to provide friendly and courteous service to consumers.

12) Good fruit quality (taste and aroma). Strawberry barn has strawberry fruit that has a sweet and fresh taste and a fragrant aroma. The Kota Batu strawberries have a different taste from the Bandung City strawberries, such as a better taste and a more fragrant aroma than the strawberries in Bandung, even though they are quite small or medium in size.

13) Different packaging from others. Strawberry barn has a different packaging or packaging from competitors, namely duplex material covered with vinyl. This material is more environmentally friendly than mica and cheaper than other materials. In addition, duplex material can maintain the quality of the fruit so it doesn't run out quickly and is safer.

14) Ability in fruit sorting and fruit quality control. Every major harvest, the strawberry barn sorts the fruit which is divided into three groups, namely grade $A$, grade $B$, and grade $C$. Sorting is done by farmers and will be re-sorted by the strawberry barn to ensure the appropriate grade.

- Weaknesses:

1) Unclear marketing of strawberries after harvest. Although the strawberry barn has managed strawberry fruit products, it still has not overcome the problems related to the marketing of strawberries during the main harvest. 
2) Few human resources. The labor force in the strawberry barn is very few, only five people.

3) During the pandemic, rarely visitors come. At the beginning of the COVID-19 pandemic, many tours were closed, one of which was the strawberry barn. This is due to following government regulations where people are prohibited from being in crowds and must keep their distance.

4) During rainy season, strawberry fruit drop. In the rainy season, many strawberry plants in the strawberry barn are damaged and the strawberry barn still has not implemented a green house in the strawberry barn to overcome this problem.

5) Small fruit size. Strawberries in the strawberry barn on average have small to medium fruit sizes. Strawberries for the area around Batu on average use the same variety, however, the results obtained are different. For example, in the Pujon area where they have strawberries that are slightly larger than the strawberry barns.

6) Strawberry lasts only two days. Strawberries for the area around Batu last only two days on average. When compared with Bandung strawberries where the strawberries can last up to one week. Therefore, the strawberry barn will immediately sell the harvest and that day must also run out, if there is left it will be frozen.

External factors can be identified as opportunities and threats for the development of strawberry barns. The following are the results of the analysis of opportunities and threats owned by the Strawberry Barn.

- Opportunities:

1) Strawberry product management. The strawberry barn collaborates with PKK women to manage processed strawberry products, such as fruit juice and jam. In addition, the Strawberry Barn also manages strawberries into ice cream products, frozen fruit and strawberry juice.

2) Making product innovations. One of the efforts made by the Strawberry Barn is to make new innovations which can be the advantages of the Strawberry Barn. The innovation that has been made is changing the packaging. In addition, the Strawberry Barn has the idea to make dried strawberries and improve the system on the Strawberry Barn's official website. Strawberry barn wants to improve the system on its website where later visitors can see the number of visitors who are already in the strawberry barn with the aim of avoiding the accumulation of visitors.

3) Natural conditions that support to develop strawberry picking tourism. The strawberry barn is located in a highland area which is located at an altitude of $700-800$ meters above sea level, has an optimum air temperature of around $15-25^{\circ} \mathrm{C}$ and a minimum temperature of $3-5^{\circ} \mathrm{C}$, has an air humidity of $85-91 \%$ with a sun exposure of $7.9-9,5$ hours/day, and has rainfall between $500-900 \mathrm{~mm} / \mathrm{year}$. This is in accordance with the criteria of strawberry fruit growth where strawberry plants in the strawberry barn get eight hours of sunlight per day.

4) There are consumers who help recommend picking tours and fresh strawberries to other consumers. Regular consumers owned by the strawberry barn often make repeat purchases, either returning to visit for strawberry picking tours or buying fresh strawberries. Repurchase occurs because there is trust from consumers with the strawberry barn.

5) Increase in visitors at a certain time and the number of requests each month. The number of visitors to the strawberry picking tour at the strawberry barn has increased over a certain period of time. An increase in the number of visitors usually occurs during the holiday season, weekends, Eid al-Fitr, and other major holidays. The increasing number of strawberry picking tourist visitors and fresh strawberry consumers is of course followed by an increase in the profit received by the strawberry barn.

6) It has beautiful natural scenery and there are several spots for interesting photos. Strawberry barn has very beautiful natural scenery. Usually, visitors will take a strawberry picking tour by enjoying the scenery and taking pictures while picking strawberries.

- Threats:

1) Stockpiling of strawberry fruit. Strawberry barns are still experiencing problems that cannot be overcome, namely the accumulation of stock of strawberries after the main 
harvest. If this problem has not been resolved then it is likely to be detrimental to the strawberry barn. This is because every day you can harvest strawberries, but usually harvesting is done $3 x$ a week. Strawberry barns hold the harvest from strawberry farmers so that if all of it cannot be absorbed during the main harvest, the strawberry barns will be in debt to strawberry farmers.

2) The surrounding community is still not supportive. At the beginning of the establishment of the strawberry barn, many people and middlemen felt that they were being rivaled. This is because the strawberry barn dares to take the strawberry farmers' harvest above the price from the middleman. However, at this time the local community has started to support the strawberry barn where the strawberry barn also confirms permits for every activity event at the strawberry barn.

3) Switching of consumers and visitors to other competitors. The number of other strawberry picking tours in Batu City is one of the factors that influence the development of strawberry barns. There is a possibility that potential consumers will visit other strawberry picking tours. So that it will automatically become a threat to the strawberry barn if consumers switch to other similar competitors.

4) There are competitors who have lower prices. Many competitors are doing the same type of business with the strawberry barn, followed by a variety of product prices offered. The majority factor that is considered by consumers to buy a product is the price so that it can be a certain attraction for consumers to make purchasing decisions.

Factors classified as strengths and weaknesses in the implementation of business in the strawberry barn were analyzed based on internal factor analysis. The results of the IFAS analysis through ratings, weights, and scores can be seen in the table below.

Table 7 - IFAS Analysis

\begin{tabular}{|c|c|c|c|}
\hline \multicolumn{4}{|l|}{ (S): Strength } \\
\hline Internal Factor & Weight (a) & Rating (b) & Score $(a \times b)$ \\
\hline Good reputation from consumers & 0,05 & 4,0 & 0,2 \\
\hline Family work culture & 0,03 & 4,0 & 0,12 \\
\hline Workers who help run the business & 0,04 & 4,0 & 0,16 \\
\hline Have an official account on social media & 0,05 & 4,0 & 0,2 \\
\hline Strategic location and has good facilities & 0,04 & 4,0 & 0,16 \\
\hline Solid teamwork & 0,04 & 4,0 & 0,16 \\
\hline Ability to establish good communication with consumers & 0,05 & 4,0 & 0,2 \\
\hline Ability to establish good communication with work partners & 0,05 & 4,0 & 0,2 \\
\hline Financial management ability & 0,05 & 4,0 & 0,2 \\
\hline Utilizing social media for marketing & 0,05 & 4,0 & 0,2 \\
\hline Have regular customers & 0,05 & 4,0 & 0,2 \\
\hline More visitor capacity than competitors & 0,04 & 4,0 & 0,16 \\
\hline Ability to maintain facilities & 0,03 & 4,0 & 0,12 \\
\hline Good service to consumers & 0,06 & 4,0 & 0,24 \\
\hline Has a good quality of strawberries (in terms of taste and aroma) & 0,05 & 4,0 & 0,2 \\
\hline Has a different packaging from the others & 0,05 & 4,0 & 0,2 \\
\hline Ability in fruit sorting & 0,04 & 4,0 & 0,16 \\
\hline Fruit quality control ability & 0,04 & 4,0 & 0,16 \\
\hline Weight $S=0,8$ & \multicolumn{3}{|c|}{ Score $S=3,24$} \\
\hline \multicolumn{4}{|l|}{ (W): Weakness } \\
\hline Internal Factor & Weight (a) & Rating (b) & Score $(a \times b)$ \\
\hline Still confused about the marketing of strawberries after post-harvest & 0,05 & 3,0 & 0,15 \\
\hline Few HR & 0,03 & 2,0 & 0,06 \\
\hline During the pandemic, tourist visitors rarely come & 0,02 & 1,0 & 0,02 \\
\hline During rainy season, strawberry fruit drop & 0,04 & 4,0 & 0,16 \\
\hline Strawberry size is small & 0,02 & 2,0 & 0,04 \\
\hline Strawberry lasts only 2 days & 0,03 & 1,0 & 0,03 \\
\hline Weight $W=0,2$ & \multicolumn{3}{|c|}{ Score $\mathrm{W}=0,46$} \\
\hline Total Internal Factors & 1,00 & $=3,7$ & \\
\hline
\end{tabular}

Source: Primary Data Processed (2021).

It can be seen that there are main weaknesses and main strengths in the implementation of business in the strawberry barn. Both of these can be seen from the scores on each factor. The main strength that exists in the implementation of business in the strawberry barn, namely good service to consumers of the strawberry barn, is 0.24 . Strawberry barn wants to provide the best possible service to consumers with the aim that consumers can buy products from strawberry barns in a sustainable manner and it is hoped that consumers can help promote the strawberry barn business to other consumers. 
The main weakness found in the implementation of business in the strawberry barn, namely during the rainy season there was a decrease in strawberry fruit yield, by 0.16 . So that factor is the main weakness of the strawberry barn business. This is in accordance with the statement from the strawberry barn based on the results of the interview, that during the rainy season strawberry plants have quite difficult and expensive maintenance, besides that they should not be exposed to too much water or too much sunlight.

Factors classified as opportunities and threats in the implementation of business in the strawberry barn were analyzed based on the analysis of external factors. The results of the EFAS analysis through ratings, weights, and scores can be seen in the table below.

Table 8 - EFAS Analysis

\begin{tabular}{|c|c|c|c|}
\hline \multicolumn{4}{|l|}{ (O): Opportunity } \\
\hline External Factor & Weight (a) & Rating (b) & Score $(a \times b)$ \\
\hline Strawberry product management & 0,08 & 4,0 & 0,32 \\
\hline Continue to make innovations to develop products & 0,09 & 4,0 & 0,36 \\
\hline Natural conditions that support to develop strawberry picking tourism & 0,07 & 4,0 & 0,28 \\
\hline $\begin{array}{l}\text { There are consumers who help recommend strawberry picking tours to other } \\
\text { consumers }\end{array}$ & 0,09 & 4,0 & 0,36 \\
\hline Increase in the number of visitors at a certain time & 0,09 & 4,0 & 0,36 \\
\hline It has beautiful natural scenery and there are several spots for interesting photos & 0,07 & 4,0 & 0,28 \\
\hline There are consumers who help recommend strawberries to other consumers & 0,09 & 4,0 & 0,36 \\
\hline Increasing number of requests every month & 0,09 & 4,0 & 0,36 \\
\hline Weight $\mathrm{O}=0,7$ & & \multicolumn{2}{|c|}{ Score $\mathrm{O}=2,68$} \\
\hline \multicolumn{4}{|l|}{ (T): Threat } \\
\hline External Factor & Weight (a) & Rating (b) & $\begin{array}{l}\text { Score } \\
(a \times b)\end{array}$ \\
\hline Stockpiling of strawberries & 0,09 & 4,0 & 0,36 \\
\hline The surrounding community still doesn't support the strawberry barn & 0,04 & 1,0 & 0,04 \\
\hline Diverting visitors to other strawberry picking tours & 0,05 & 1,0 & 0,05 \\
\hline There are competitors who have lower product prices & 0,09 & 3,0 & 0,27 \\
\hline Switching consumers to other strawberry sellers & 0,06 & 2,0 & 0,12 \\
\hline Weight $\mathrm{T}=0,3$ & & \multicolumn{2}{|c|}{ Score $T=0,84$} \\
\hline Total External Factor & 1,00 & $=3,52$ & \\
\hline
\end{tabular}

Source: Primary Data Processed (2021).

It can be seen that there are main opportunities and main threats in the implementation of business in the strawberry barn. Both of these can be seen from the scores on each factor. The factors that become the main opportunities have the highest scores compared to other factors, namely continuing to make innovations to develop products, the presence of consumers who help recommend strawberry picking tours to other consumers, an increase in the number of visitors at certain times, the existence of consumers who help recommend fresh strawberry products to other consumers. other consumers, and an increase in the number of requests for strawberries every month. This is in accordance with the results of interviews with the strawberry barn.

External factors that become the main threat from the implementation of the strawberry barn business, namely the accumulation of strawberries, amounted to 0.36 . Based on the results of interviews, the problem that has not been resolved until now is when the harvest season occurs when there is a pile of strawberries where the strawberry barn still lacks a market to sell fresh strawberries. However, because there are too many leftover strawberries, even though they have been processed, most of them will rot and have to be thrown away.

The SWOT matrix analysis aims to formulate a strategy that will be used in business development efforts at the Strawberry Barn to help develop BUMDes Raharjo in Pandarejo Village. This analysis is carried out by combining each of the factors, namely strengths, weaknesses, opportunities, and threats. The formulation of a business development strategy in the strawberry barn using the SWOT matrix can be seen in the table below.

There are four alternative business development strategies that can be carried out by the Strawberry Barn to improve business development. Of the four strategies are compiled based on a combination of two internal factors and external factors. The alternative strategies are composed, namely the SO strategy which combines strength and opportunity 
factors, the WO strategy is a combination of weakness and opportunity factors, the ST strategy is a combination of strength and threat factors, and the WT strategy is a combination of weakness and threat factors. The following is an explanation of each alternative strategy that can be carried out by the Strawberry Barn.

Table 9 - Matrix SWOT Analysis

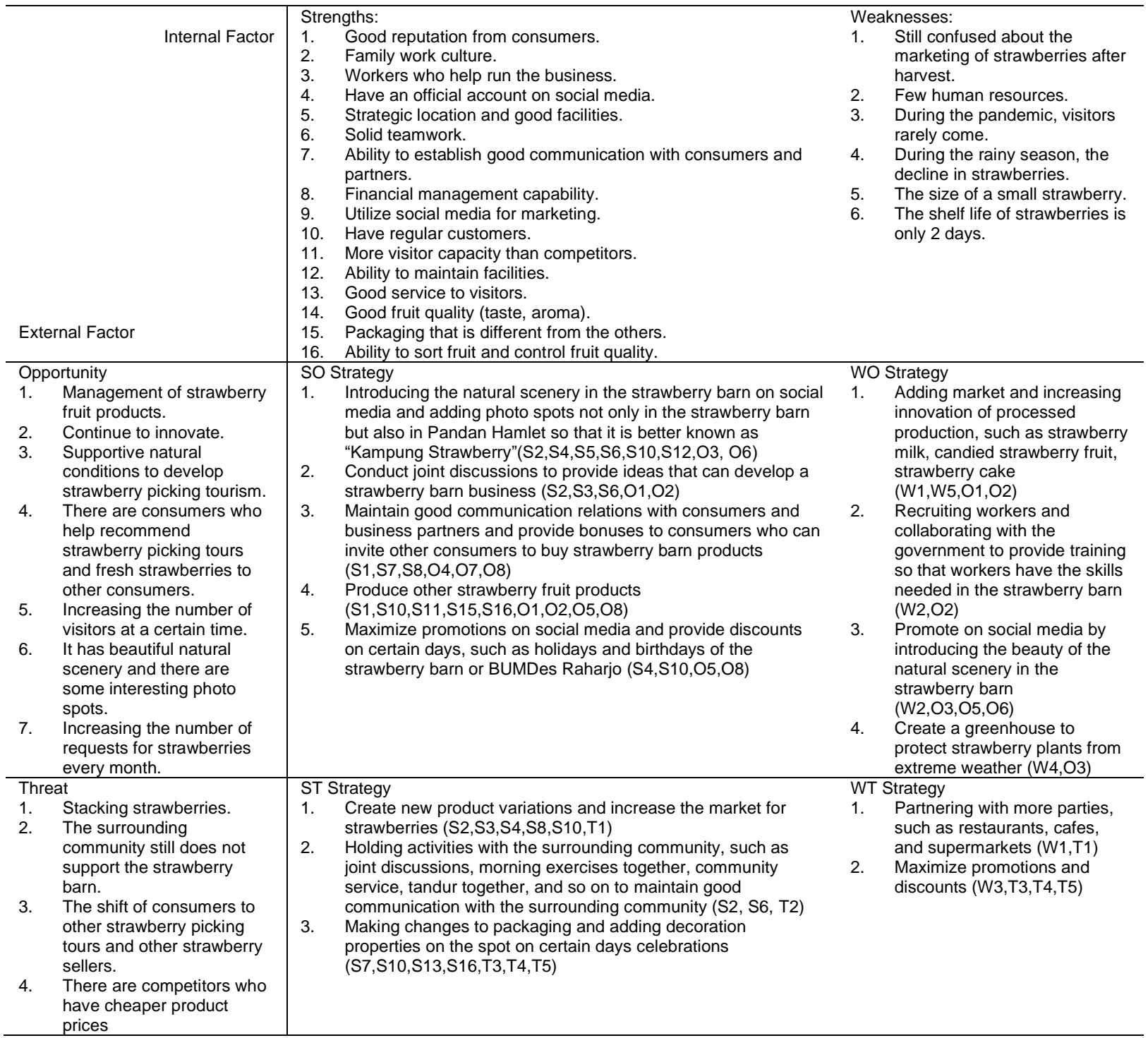

Source: Primary Data Processed (2021).

\section{SO Strategy (Strength-Opportunity):}

The first SO strategy that the Strawberry Barn can do is carry out promotions to introduce the natural scenery at the Strawberry Barn on social media and add photo spots not only at the Strawberry Barn but also in Pandan Hamlet so that tourists can be known as "Kampung Strawberry". The second strategy that can be applied by the strawberry barn is to discuss together to think of innovations that can be done which can develop the strawberry barn business. The third strategy that can be carried out by the strawberry barn is to maintain good communication relations with consumers and business partners and provide bonuses to consumers who can invite other consumers to buy strawberry barn products. The fourth strategy that can be carried out by the strawberry barn is to produce new variants of processed strawberries. Social media owned by the Strawberry Barn can be used to maximize online promotions to reach wider consumers. The last strategy that can be done by the strawberry barn is to maximize promotions on social media and provide discounts on 
certain days, such as big days and the birthday of the strawberry barn or the birthday of BUMDes Raharjo.

2. WO Strategy (Weakness-Opportunity):

The strategy that can be applied through a combination of weakness and opportunity factors from the strawberry barn is to increase the market and increase innovation in the production of processed strawberries, such as strawberry milk, candied strawberries, and strawberry cake. This strategy is carried out in the hope of overcoming marketing problems during the harvest season. The second strategy that can be carried out by the Strawberry Barn is to recruit workers and ask the government to conduct training for workers and the surrounding community in certain fields. The next strategy is to carry out promotions on social media by introducing beautiful natural scenery at the strawberry barn and displaying the results of reviews from consumers who have purchased strawberry barn products. The last strategy that can be done by the strawberry barn is to make a greenhouse. This strategy aims to protect strawberry plants from extreme weather.

3. ST Strategy (Strength-Threat):

The strategy of a combination of strength factors and threat factors that can be applied by the Strawberry Barn is to innovate new products and add to the market. This strategy aims to overcome the problem of stockpiling strawberries. The second strategy that can be applied to the strawberry barn business is holding joint activities with the surrounding community. This strategy is expected to maintain good communication relations with the surrounding community so that the surrounding community can trust the strawberry barn. Activities from this strategy can be carried out, such as morning exercises together every weekend, community service, joint discussions related to village development, tandur together, and so on. The next strategy is to change the form of special packaging and add special decorative properties in accordance with the celebration of major holidays, such as Eid al-Fitr. The innovation of changing packaging is adjusted to the sales theme of celebrating certain days and increasing buying interest from consumers. This strategy is expected to minimize the impression of boredom from consumers and is expected to create a new atmosphere for consumers.

4. WT Strategy (Weakness-Threat):

An alternative strategy from the combination of weakness and threat factors that can be done by the strawberry barn is to partner with more parties, such as restaurants, cafes, and supermarkets. This strategy aims to overcome marketing during the main harvest which can cause stockpiling of strawberries. The next strategy is to maximize promotions and discounts. This strategy is expected to maintain consumer loyalty to continue buying strawberry barn products.

After formulating alternative strategies for business development efforts in the strawberry barn, the next step is to conduct an analysis to determine the $\mathrm{X}$-axis and $\mathrm{Y}$-axis coordinate points. The $X$-axis points are obtained from the calculation of the internal factor scores, while the $\mathrm{Y}$-axis points are obtained from the calculation of the factor scores. external. Through the meeting of the two points, it is possible to identify strategic priorities that need to be carried out first from other strategies. The following are the details of the calculation of each coordinate point in the SWOT quadrant both from internal factors and external factors in carrying out business in the Strawberry Barn.

Table 10 - Details of Calculation of Coordinate Points in the SWOT Quadrant

\begin{tabular}{llll}
\hline Score Internal Factor & Score External Factor & 2,68 \\
\hline Strength & 3,24 & Opportunity & 0,84 \\
\hline Weakness & 0,46 & Threat & 1,84 \\
\hline X-axis & 2,78 & Y-axis & \\
\hline
\end{tabular}

Source: Primary Data Processed (2021).

The table above explains that the details of the calculation of each score are both internal and external factors. The X-axis coordinates point to 2.78. These results were obtained from the results of reducing the score of the strength factor and weakness factor, 
namely $3.24-0.46=2.78$. The $\mathrm{Y}$-axis coordinates point to 1.84 . These results were obtained from the results of reducing the score of the opportunity factor and the threat factor, namely $2.68-0.84=1.84$. Through the two coordinate points that have been obtained, it can be seen the position of the intersection point between the $X$ and $Y$ axes which is defined as the strategic position that is prioritized to be applied first. The following are the results of the SWOT quadrant on business implementation in the strawberry barn.

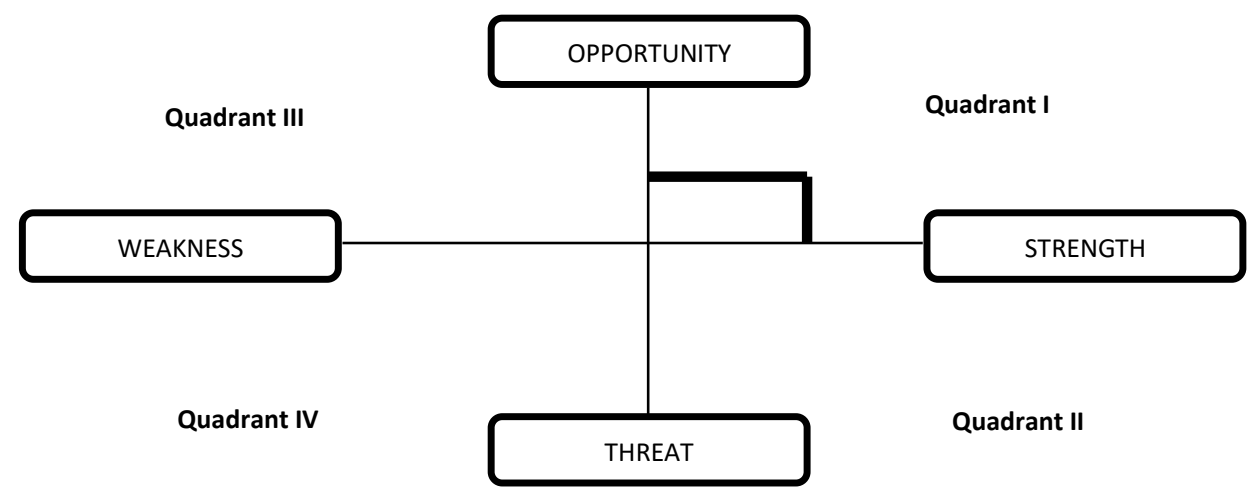

Figure 5 - SWOT Quadrant Results (Source: Primary Data Processed, 2021)

The results of the SWOT quadrant above show that the results of the intersection of the coordinates on the $X$ axis and $Y$ axis describe the position of the SWOT quadrant. In the picture above, it is known that the intersection of the coordinate points is in quadrant I. Quadrant I illustrates the need for a strategy that supports growth aggressively (growth oriented strategy). Based on the statement of Yuliana (2013), that if the quadrant is position I, the appropriate alternative strategy is the SO strategy.

Research Implication. Based on the results of the SWOT analysis of the identification of internal factors and external factors in the strawberry barn business, it is known that the strawberry barn business is in quadrant I where the appropriate alternative strategy is the SO (Strength - Opportunity) strategy, which is a combination strategy of the existing strength and opportunity factors in the strawberry barn. The position of quadrant I shows that the strawberry barn is in a profitable business condition where the strawberry barn has strengths and opportunities that can be exploited simultaneously by maximizing existing opportunities, so that the best strategy to implement is the strategy by creating an aggressive growth policy.

Based on this, the SO strategy that needs to be prioritized by the Strawberry Barn, one of which is to innovative products and produce new variants of processed strawberry products, such as strawberry milk, candied strawberries, snacks, and innovations that have been planned by the Strawberry Barn, namely dried strawberries. . Processed milk and strawberry snacks can be served on the menu for the cafe where visitors can immediately enjoy the food and drinks with an atmosphere that is supported by a beautiful view in the strawberry barn. This innovation is possible to increase consumer buying interest with new products. So that it will create new product developments and can be introduced through various social media from the strawberry barn.

The SO strategy that can also be applied by the Strawberry Barn is to hold joint discussions to provide ideas that can develop the Strawberry Barn business. This is done to create new innovations and strengthen relations between workers. Strawberry barn has also implemented this strategy in its business where they often gather together to give each other new ideas, chat together to discuss the problems they are facing, and have coffee together to strengthen the relationship between workers so that they are more solid.

Another SO strategy is to carry out promotions to introduce the beautiful natural scenery at the strawberry barn through social media and add photo spots not only in the strawberry barn but also in Pandan Hamlet so that tourists can be known as the "Strawberry Village". This can make it possible to attract consumers to visit the strawberry barn because 
it presents interesting photo spots and natural scenery. Satisfied tourists visiting the strawberry barn will increase tourist loyalty, such as returning to visit and conducting promotions to other potential consumers.

The SO strategy that can be applied by the strawberry barn is to maximize promotions on social media and provide discounts on certain days, such as big celebrations and the birthday of the strawberry barn or the birthday of BUMDes Raharjo. This strategy aims to introduce strawberry barns and BUMDes Raharjo so that they are more widely known by consumers. In addition, to maintain consumer loyalty so as not to switch to competitors who have cheaper prices and make consumers' buying interest even greater. Through the provision of promotional information on social media at certain times this can be done optimally to maximize opportunities to increase the number of sales.

The SO strategy that can also be applied by the Strawberry Barn is to maintain good communication relations with consumers and business partners and provide bonuses to consumers who can invite other consumers to buy Strawberry Barn products. By maintaining a good relationship with consumers can affect customer satisfaction. This is because consumers will have more confidence in the strawberry barn. In addition to good communication relations, customer satisfaction is also influenced by service quality.

\section{CONCLUSION}

The conclusions obtained are based on the results of research that has been carried out regarding the development strategy of one of the business units of BUMDes Raharjo in Pandanrejo Village, Batu City, namely the Strawberry Barn, among others, as follows:

1. The results of the VRIO analysis (value, rarity, Imitability, and organization) show that there is one resource and capability of the Strawberry Barn that has a "sustainable competitive advantage", namely having packaging for strawberries which is different from others and innovating to create product excellence. In addition, there are resources that are "temporary competitive advantage", namely the capacity of visitors is more than competitors. These resources and capabilities show that the potential in the Strawberry barn is a competitive advantage and can maintain these advantages;

2. The results of the SWOT analysis show that the strategic priorities are in quadrant I where the implementation of strategies that support growth is aggressive. This strategy is a combination of the strengths and opportunities possessed by the Strawberry Barn, namely the SO (strength-opportunity) strategy which is considered to be profitable for business implementation. Strengths possessed by the Strawberry Barn are a good reputation from consumers, a family work culture and solid teamwork, a workforce that helps run the business, has an official account on social media and uses it for marketing, a strategic location and has good facilities, the ability to establish good communication with consumers and business partners, the ability to manage finances, have regular customers, the capacity of visitors is more than competitors, the ability to maintain facilities, good service to visitors, good fruit quality (in terms of taste and aroma), packaging different from competitors, and the ability to sort and control fruit quality. In addition, the opportunities that exist in the strawberry barn which can be utilized, namely the management of products from strawberries, making product innovations, natural conditions that support the development of strawberry picking tourism, the existence of consumers who help recommend picking tours and fresh strawberries to other consumers, an increase in visitors at certain times and the number of requests every month, and has beautiful natural scenery and there are several interesting photo spots;

3. The priority business development strategy that can be applied to one of Raharjo's BUMDes business units "Lumbung Strawberry" is (1) Introducing the natural scenery in the strawberry barn on social media and adding photo spots not only in the strawberry barn but also in Pandan Hamlet so that better known as "The Strawberry Village". (2) Conduct joint discussions to provide ideas that can develop a strawberry barn business. (3) Maintain good communication relations with consumers and business partners and provide bonuses to consumers who can invite other consumers to buy strawberry barn products. (4) Producing 
other processed strawberry fruit products. (5) Maximizing promotions on social media and providing discounts on certain days, such as holidays and birthdays of the strawberry barn or BUMDes Raharjo. (6) Providing easy access to transportation. (7) Pay more attention to the quality of the fruit that will be offered to consumers.

\section{SUGGESTIONS}

Suggestions that can be given by the strawberry barn are to add human resources who have the ability and skills that match the criteria of the strawberry barn so that the performance of each workforce is better and add resellers for the strawberry market and to overcome existing problems. In addition, the strawberry barn must maintain the trust that has been given by consumers by paying attention to the quality of the fruit that will be offered both in terms of size, taste, and color. Strawberry barns must also maintain their strengths in order to take advantage of existing opportunities so that their weaknesses can be reduced gradually.

Suggestions for further researchers are to be able to examine in more detail the business activities that have been carried out and evaluate the implementation of strategies for business management carried out to reduce weaknesses, namely one of the shortages of the market for strawberries and the need for follow-up related to the marketing strategy carried out by the strawberry barn. In addition, it is hoped that they can establish good communication with the Strawberry Barn so that the research carried out can run smoothly.

\section{REFERENCES}

1. Agunggunanto, E.Y., Fitrie A., Edi W.K., \& Darwanto. (2016). Pengembangan Desa Mandiri melalui Pengelolaan Badan Usaha Milik Desa (BUMDes). Jurnal Dinamika Ekonomi \& Bisnis, 13(1), 67-81.

2. Chikmawati, Z. (2019). Peran BUMDes dalam Meningkatkan Pertumbuhan Ekonomi Pedesaan melalui Penguatan Sumber Daya Manusia. Jurnal Istriqo: Jurnal Hukum Islam, Ekonomi and Bisnis, 5(1), 101-113.

3. Ermaya, S.K., and Nana D. (2019). Strategi Pengembangan Bisnis dengan Pendekatan Business Model Canvas (Studi Kasus: Industri Kecil Kerupuk). Business Management and Entrepreneurship Journal, 1(3), 201-218.

4. Fajar, A. (2020). 6.080 BUMDes Jatim Terdaftar, Hanya 456 yang Masuk Kategori Maju. Diakses dari https://jatim.idntimes.com/news/jatim/ardiansyah-fajar/6080-bumdes-jatimterdaftar-hanya-456-yang-masuk-kategori-maju/3.

5. Fitriska, K. (2017). Strategi Pengembangan Badan Usaha Milik Desa dalam Meningkatkan Kesejahteraan Masyarakat di Desa Lancang Kuning Kecamatan Bintan Utara. Jurnal Ilmu Administrasi Negara (JUAN), 5(2), 29-34.

6. Kim, S-C., Lee, J-S. \& Shin, K-I. (2015). The Impact of Project Management Assets on The VRIO Characteristic of PM Process for Competitive Advantage. Int. J. Productivity and Quality Management, 15(2), 153-168.

7. Prasetyo, B.B. et al (2018). Strategi Pengembangan Bisnis Rhythm of Empowerment dengan Pendekatan Model Bisnis Kanvas. J. Aplikasi Manaj. and Bisnis, 4(2), 296-307.

8. Presiden Republik Indonesia. (2014). Peraturan Pemerintah Nomor 43 tahun 2014 Tentang Peraturan Pelaksanaan Undang-Undang Nomor 6 tahun 2014 Tentang Desa Pasal 1 ayat 7. Diakses pada tanggal 19 Januari 2020 dari https://www.bkn.go.id/wpcontent/uploads/2015/06/pp-nomor-43-tahun-2014-peraturan-pelaksanaan-undangundang-nomor-6-tahun-2014-tentang-desa.pdf

9. Rangkuti, F. (2014). Analisis SWOT: Teknik Membedah Kasus Bisnis. Jakarta: PT Gramedia Pustaka Utama.

10. Ridlwan, Z. (2014). Urgensi Badan Usaha Milik Desa (BUMDes) dalam Pembangunan Perekonomian Desa. Fiat Justisia Jurnal IImu Hukum, 8(3), 424-440.

11. Yuliana, A.E. (2013). Strategi Pengembangan Industri Kecil Kerajinan Genteng di Kabupaten Kebumen. Economics Development Analysis Journal (EDAJ), 2(3), 24-34. 